\title{
Physical-Mechanical Properties of Laminated Board Made from Oil Palm Trunk (Elaeis guineensis Jacq.) Waste with Various Lamina Compositions and Densifications $^{1}$
}

\author{
Dita Sari PRABUNINGRUM ${ }^{2} \cdot$ Muh Yusram MASSIJAYA (D) $^{2, \dagger} \cdot$ \\ Yusuf Sudo $\mathrm{HADI}^{2} \cdot$ Imam Busyra ABDILLAH ${ }^{2}$
}

\begin{abstract}
The purpose of this study was to investigate a method for improving the physical and mechanical properties of laminated board made from oil palm trunk (OPT). The effects of pretreating the lamina with heat-pressure and altering the lamina composition of the laminated board were investigated. The outer third of OPT in cross-section had high-density wood, while the underlying third had low to medium density. The hot press was applied to pretreat the lamina that had low to medium density. The lamina were $1.5 \mathrm{~cm}$ in thickness, $5 \mathrm{~cm}$ in width, and $65 \mathrm{~cm}$ in length. The hot press was applied at $2.94 \mathrm{MPa}$ or $4.41 \mathrm{MPa}$ at $150{ }^{\circ} \mathrm{C}$ for 60 minutes, and the target thickness of the lamina was $1 \mathrm{~cm}$. The three layers of the laminated board samples were bonded with isocyanate adhesive at a glue spread of $300 \mathrm{~g} / \mathrm{m}^{2}$ and cold pressed at $0.98 \mathrm{MPa}$ for $3 \mathrm{~h}$. The laminated board samples were tested according to Japanese Agricultural Standard (JAS) 234-2003. The results showed that the densification of the inner lamina did not significantly affect the physical-mechanical properties of the laminated board produced. However, the laminated board made with high-density laminas for the outer layers fulfilled the JAS 234-2003 standard for the modulus of elasticity and the modulus of rupture.
\end{abstract}

Keywords: laminated board, pretreatment, hot-press, oil palm trunk, densification, lamina combination

\section{INTRODUCTION}

The area occupied by oil palm plantations in Indonesia is increasing every year. Based on the Indonesian Plantation Statistics on Palm Oil Commodities (Directorate General of Estate Crops, 2018), the area increased by $67.5 \%$ from 2010 to 2017 , from $8,385,394$ ha in 2010 to $14,048,722$ ha in 2017 . As the total oil palm plantation area has become larger, the production of palm oil stem waste has consistently become greater as well. The productive period of the oil palm is 5-25 years, and after more than 25 years, it will be felled and replaced with a new oil palm. During this process, the amount of waste products can reach $220 \mathrm{~m}^{3} / \mathrm{ha}$, while as much

\footnotetext{
${ }^{1}$ Date Received January 22, 2019, Date Accepted March 5, 2020

2 IPB University (Bogor Agricultural University), Kampus IPB Darmaga, Bogor 16680, Indonesia.

$\dagger$ Corresponding author: Muh Yusram MASSIJAYA (e-mail: mymassijaya@yahoo.co.id, ORCID: 0000-0002-9538-6326).
} 
Physical-Mechanical Properties of Laminated Board Made from Oil Palm Trunk

(Elaeis guineensis Jacq.) Waste with Various Lamina Compositions and Densifications

as $50-75 \mathrm{~m}^{3} /$ ha of sawn timber can be obtained from the trunks of felled trees (Balfas, 2006; Febrianto and Bakar, 2004; Hambali and Rivai, 2017). The total amount of oil palm waste production indicating the total volume of harmful carbon dioxide emission based on its life cycle inventory (Chang et al., 2016). Due to these reasons, the oil palm waste very potential to be utilized as bio-composite products raw materials.

In oil palm plantations, unproductive stands produce waste in the form of oil palm trunk (OPT). Trunks are typically destroyed by being burned or left to rot, which can attract insect pests that may attack healthy trees in oil palm plantations. A considerable amount of research has focused on finding uses for OPT and enhancing its economic value. OPT tends to be more cylindrical than the trunks of other wood species. It can be predicted that OPT will had yield (Jeong et al., 2016). One option for using OPT is in the manufacture of products such as laminated boards. However, composite products that have been selected for studying the use of OPT contain many weaknesses in terms of dimensional stability, strength, and durability (Way et al., 2010; Hartono, 2012).

The wood used for structural purposes must have strength and durability. In particular, the wood for buildings should have strength class I-III and durability class II-III (Martawijaya et al., 2005). Pramunendar and Supriyanto (2014) reported three classes of density for sawn timber: high density $\left(\geq 0.70 \mathrm{~g} / \mathrm{cm}^{3}\right)$, medium density $\left(\geq 0.50-0.70 \mathrm{~g} / \mathrm{cm}^{3}\right)$, and low density $(<0.50 \mathrm{~g} /$ $\left.\mathrm{cm}^{3}\right)$. Strength classes according to Martawijaya et al. (2005) can be seen in Table 1.

A large amount of research has been conducted on laminated board made from OPT. Several studies used the outer third of OPT (Darwis et al., 2014b), while others used low-density OPT for the core of the laminated board, plywood for the face, and high-density OPT for the back (Tarigan et al., 2015). In other studies, the innermost layer made from low-density OPT was
Table 1. Wood strength class

\begin{tabular}{cc}
\hline Strength class & Modulus of rupture $(\mathrm{MPa})$ \\
\hline \hline I & $>108$ \\
II & $71-108$ \\
III & $49-71$ \\
IV & $35-49$ \\
V & $<35$ \\
\hline
\end{tabular}

Source: Martawijaya et al. (2005)

compressed with a specific pressure of $3.43 \mathrm{MPa}$ (Hartono et al., 2011; 2012) to avoid defects during processing (Song and Hong, 2016), but the products could not be used for structural purposes. Altogether, these studies indicate that raw materials with high density and modulus of elasticity (MOE) must be used for the outer layers for best performance of laminated boards (Byeon et al., 2017; 2018).

Based on these findings, the author aimed to improve the physical and mechanical properties of laminated board constructed from OPT by utilizing the outer third of OPT in cross-section for the face layers and the less-dense underlying third for the core layer. Densification of low- to medium-density lamina was done by hot press at $150{ }^{\circ} \mathrm{C}$ for 60 minutes with pressure at $2.94 \mathrm{MPa}$ or $4.41 \mathrm{MPa}$. Various combinations of laminas were used to create OPT laminated board. Improvement of the physical and mechanical properties of OPT laminated boards was then tested.

\section{MATERIALS and METHODS}

\subsection{Preparation of raw materials}

The OPT used as raw material in this study was taken from an unproductive stand that was more than 25 years old, and the laminas were produced from the outermost two-thirds of the OPT. The outer third of the trunk in cross-section had high-density wood, while the underlying third had low- to medium-density wood. The laminas were sorted based on their MOE value 
using nondestructive testing, according to Lestari et al. (2018). In brief, the laminas were placed on two pedestals, and then a load was applied to each lamina for measurement of the magnitude of deflection using a deflectometer. A smaller MOE value indicated a larger deflection value and vice versa. The laminas were graded and sorted into two grades, high MOE (group E1) and low MOE (group E2).

\subsection{Lamina densification}

Through densification, laminas that were originally $5 \mathrm{~cm} \times 1.5 \mathrm{~cm} \times 65 \mathrm{~cm}$ (in width, thickness, and length, respectively) became $5 \mathrm{~cm} \times 1 \mathrm{~cm} \times 65 \mathrm{~cm}$. Prior to densification, the density of lamina ranged from 0.20 to $<0.70 \mathrm{~g} / \mathrm{cm}^{3}$. The laminas were hot compressed at $150{ }^{\circ} \mathrm{C}$ for 60 minutes with specific pressures at 2.94 $\mathrm{MPa}$ or $4.41 \mathrm{MPa}$.

\subsection{Laminated board manufacture}

Laminated boards measuring $5 \mathrm{~cm} \times 3 \mathrm{~cm} \times 65 \mathrm{~cm}$ (width, thickness, and length, respectively) were composed of three layers of lamina measuring $5 \mathrm{~cm}$ $\times 1 \mathrm{~cm} \times 65 \mathrm{~cm}$. Each treatment consisted of five replications. The laminas were categorized as high density $(\mathrm{H})\left(\geq 0.60 \mathrm{~g} / \mathrm{cm}^{3}\right)$ or low to medium density (L) $(0.20-0.60) \mathrm{g} / \mathrm{cm}^{3}$. The low- to medium-density laminas were pretreated with hot press with pressure at $2.94 \mathrm{MPa}$ or $4.41 \mathrm{MPa}$ to produce $\mathrm{L}_{30}$ and $\mathrm{L}_{45}$ laminas, respectively. Untreated low-density lamina $\left(\mathrm{L}_{0}\right)$ was also prepared for comparison purposes. Three layers of laminas (face-core-back layers) were combined in the following arrangements: $\mathrm{L}_{0} \mathrm{~L}_{0} \mathrm{~L}_{0}, \mathrm{~L}_{30} \mathrm{~L}_{30} \mathrm{~L}_{30}$, $\mathrm{L}_{45} \mathrm{~L}_{45} \mathrm{~L}_{45}, \mathrm{HL}_{0} \mathrm{H}, \mathrm{HL}_{30} \mathrm{H}$, and $\mathrm{HL}_{45} \mathrm{H}$, as shown in Fig. 1.

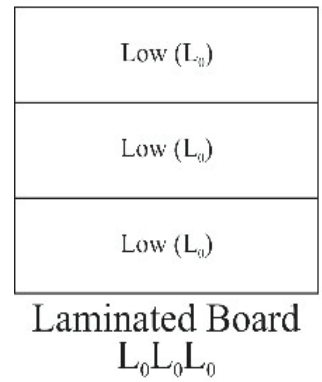

\begin{tabular}{|c|}
\hline High $(\mathrm{H})$ \\
\hline Low $\left(\mathrm{L}_{0}\right)$ \\
\hline High $(\mathrm{H})$ \\
\hline Laminated Board
\end{tabular}

$\mathrm{HL}_{0} \mathrm{H}$
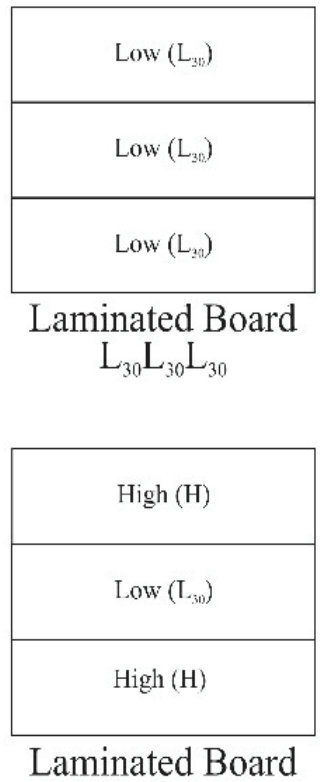

$\mathrm{HL}_{30} \mathrm{H}$
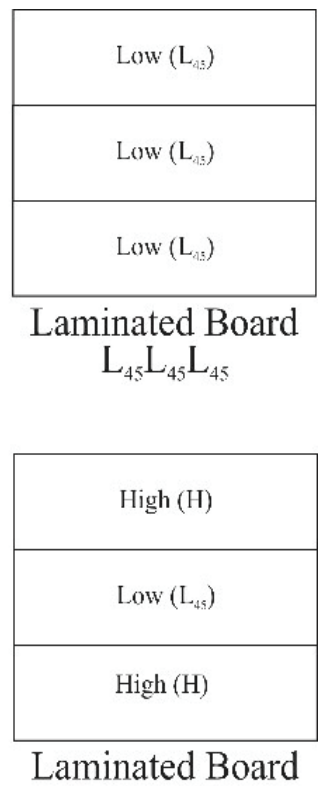

$\mathrm{HL}_{45} \mathrm{H}$

Fig. 1. The arrangements combinations of lamina. $H$, high-density; $\mathrm{L}_{0}$, low to medium density without densification; $\mathrm{L}_{30}$, low to medium density compressed with a specific pressure $2.94 \mathrm{MPa} ; \mathrm{L}_{45}$, low to medium density compressed with a specific pressure of $4.41 \mathrm{MPa}$. 
Physical-Mechanical Properties of Laminated Board Made from Oil Palm Trunk (Elaeis guineensis Jacq.) Waste with Various Lamina Compositions and Densifications

\subsection{Gluing process}

The adhesive used to bond the laminas was isocyanate with a ratio of base to hardener of 100:15 based on weight, with a glue spread of $300 \mathrm{~g} / \mathrm{m}^{2}$ (Darwis et al., 2014a). This adhesive is produced by Polyoshika Company Ltd Japan and distributed by PT Polychemie Asia Pasific Indonesia.

\subsection{Compression and conditioning}

The laminated boards were produced using a cold pressing system (Hong et al., 2017). After the adhesives were spread on their surfaces, the laminas were pressed together while the resin cured. Compression was carried out with a cold press machine using a specific pressure of $0.98 \mathrm{MPa}$ for 3 hours (Darwis et al., 2014a). Afterward, the laminated boards were conditioned for 1 week at room temperature. The manufacture of laminated board manufacturing is depicted in Fig. 2.

\subsection{Testing methods and data analysis}

Testing of the physical and mechanical properties of the laminated board was carried out based on Japanese Agricultural Standard (JAS) 234-2003 (JAS, 2003) regarding glued laminated timber. The physical properties tested were density and moisture content (MC). The mechanical properties tested were MOE, modulus of rupture (MOR), and shear strength. MOE and MOR tests use one-point loading with a span length of $42 \mathrm{~cm}$ and a loading speed of $3 \mathrm{~mm} / \mathrm{min}$. The MOE, MOR, and shear strength were calculated as follows:

$$
\begin{aligned}
& \operatorname{MOE}(\mathrm{MPa})=\Delta \mathrm{P} \cdot \mathrm{L}^{3} /\left(4 \cdot \Delta \mathrm{Y} \cdot \mathrm{b} \cdot \mathrm{h}^{3}\right) \\
& \mathrm{MOR}(\mathrm{MPa})=3 \cdot \mathrm{P} \cdot \mathrm{L} /\left(2 \cdot \mathrm{b} \cdot \mathrm{h}^{2}\right) \\
& \text { Shear strength }(\mathrm{MPa})= \\
& \quad \text { Rupture load/Area of bonding layer }
\end{aligned}
$$

where $\Delta \mathrm{P}$ is the difference between the upper and lower

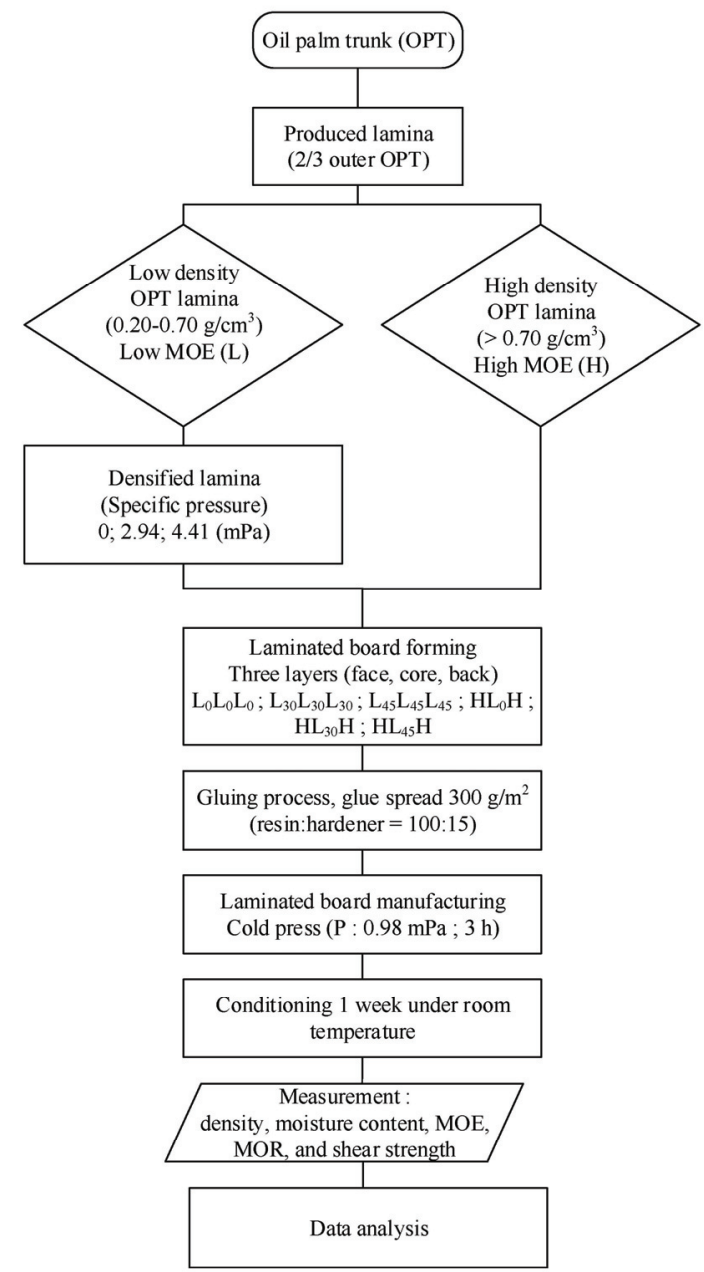

Fig. 2. Scheme of laminated board manufacturing.

loading limits in the proportional limit region $\left(\mathrm{kg}_{\mathrm{f}}\right)$; $\Delta \mathrm{Y}$ is the deflection with respect to $\Delta \mathrm{P}(\mathrm{cm}) ; \mathrm{L}$ is span $(\mathrm{cm}), \mathrm{b}$ and $\mathrm{h}$ are width and thickness of the laminated board, respectively $(\mathrm{cm})$; and $\mathrm{P}$ is the maximum loading $\left(\mathrm{kg}_{\mathrm{f}}\right)$. This study used a factorial $(2 \times 3)$ in completely randomized design. The first factor was the arrangement of laminas (i.e., the combination of $\mathrm{L}$ and $\mathrm{H}$ laminas), and the second factor was the densified lamina (i.e., $\mathrm{L}_{0}, \mathrm{~L}_{30}, \mathrm{~L}_{45}$ ). Duncan's multi range test was used for further analysis if a factor was significantly different at $\mathrm{P} \leq 0.05$. 
Dita Sari PRABUNINGRUM • Muh Yusram MASSIJAYA • Yusuf Sudo HADI - Imam Busyra ABDILLAH

Table 2. Analysis of variance of the physical and mechanical properties of the OPT laminated boards

\begin{tabular}{cccc}
\hline Parameter & $\begin{array}{c}\text { The arrangements } \\
\text { combination }(\mathrm{A})\end{array}$ & $\begin{array}{c}\text { The densified lamina } \\
\text { core part }(\mathrm{B})\end{array}$ & $\begin{array}{c}\text { Interaction } \\
(\mathrm{AxB})\end{array}$ \\
\hline \hline MC $(\%)$ & $*$ & $* *$ & $* *$ \\
Density $\left(\mathrm{g} / \mathrm{cm}^{3}\right)$ & $* *$ & $\mathrm{NS}$ & $\mathrm{NS}$ \\
$\mathrm{MOE}(\mathrm{GPa})$ & $* *$ & $\mathrm{NS}$ & $\mathrm{NS}$ \\
MOR $(\mathrm{MPa})$ & $* *$ & $\mathrm{NS}$ & $\mathrm{NS}$ \\
Shear strength $(\mathrm{MPa})$ & $\mathrm{NS}$ & $\mathrm{NS}$ & $\mathrm{NS}$ \\
\hline
\end{tabular}

Description: **very significant $(\mathrm{P}<0.01)$; *significant $(\mathrm{P}<0.05)$; NS: not significant

\section{RESULTS and DISCUSSION}

\subsection{Moisture content}

The MC of laminated boards ranged from $12 \%$ to 13\% (Fig. 3). The MC of all laminated boards met the JAS 234-2003 standard, which requires a maximum value of $15 \%$. Kretschmann and Green (1996) stated that $\mathrm{MC}$ and density are basic quality indicators that influence the strength of wood: the lower the MC, the higher the wood strength. The average MC of all the laminated boards was $12.0 \%$ because the constituent laminas had $\mathrm{MC}$ values ranging from $10 \%$ to $12 \%$. Komariah et al. (2015) stated that the MC of laminated board is influenced by the MC of each constituent lamina.

Based on the analysis of variance shown in Table 2, the MC of laminated board was influenced by how the laminas were arranged, the use of densified laminas, and the interaction of the two factors. Duncan's

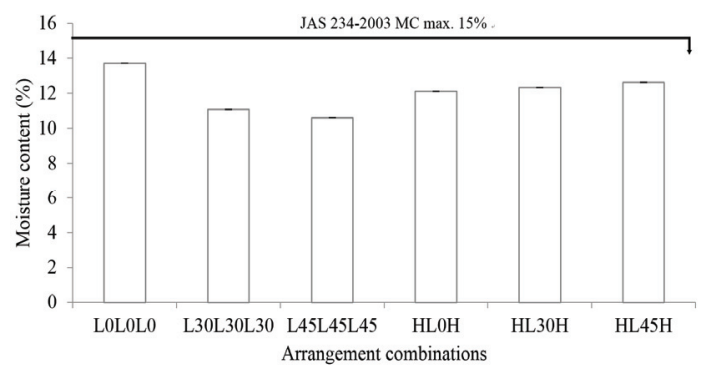

Fig. 3. MC value of the laminated board.
Table 3. Duncan's multiple range test for moisture content of the laminated board

\begin{tabular}{cccc}
\hline \multirow{2}{*}{$\begin{array}{c}\text { Combination } \\
\text { of lamina arrangements }\end{array}$} & \multicolumn{3}{c}{ Pressure (MPa) } \\
\cline { 2 - 4 } & 0 & 2.94 & 4.41 \\
\hline \hline LLL & $13.73 \mathrm{c}$ & $11.08 \mathrm{a}$ & $10.61 \mathrm{a}$ \\
HLH & $12.12 \mathrm{~b}$ & $12.33 \mathrm{~b}$ & $12.63 \mathrm{~b}$ \\
\hline
\end{tabular}

Description: Values followed by the same letter are not statistically different.

advanced test results (Table 3) showed that the laminated board composed of laminas arranged as $\mathrm{L}_{30} \mathrm{~L}_{30} \mathrm{~L}_{30}$ and $\mathrm{L}_{45} \mathrm{~L}_{45} \mathrm{~L}_{45}$ had the lowest $\mathrm{MC}$ values, 11.08 $\%$ and $10.61 \%$, compared with the boards composed of $\mathrm{L}_{0} \mathrm{~L}_{0} \mathrm{~L}_{0}(13.73 \%), \mathrm{HL}_{0} \mathrm{H}(12.12 \%), \mathrm{HL}_{30} \mathrm{H}$ (12.33\%), and $\mathrm{HL}_{45} \mathrm{H}(12.63 \%)$. The arrangements $\mathrm{L}_{30} \mathrm{~L}_{30} \mathrm{~L}_{30}$ and $\mathrm{L}_{45} \mathrm{~L}_{45} \mathrm{~L}_{45}$ were not significantly different from each other, and both were significantly different from $\mathrm{L}_{0} \mathrm{~L}_{0} \mathrm{~L}_{0}$, $\mathrm{HL}_{0} \mathrm{H}, \mathrm{HL}_{30} \mathrm{H}$, and $\mathrm{HL}_{45} \mathrm{H}$ boards. The difference was likely due to the laminas having been treated by hot pressing, which would have forced out the water inside the cell and thereby changed the cell structure of the wood. Due to the cells shrinking, the MC would have decreased (Amin and Dwianto, 2006).

\subsection{Density}

The density of the laminated boards produced ranged from $0.45 \mathrm{~g} / \mathrm{cm}^{3}$ to $0.84 \mathrm{~g} / \mathrm{cm}^{3}$, with the highest density being obtained with the laminas combined as $\mathrm{HL}_{30} \mathrm{H}$ $\left(0.85 \mathrm{~g} / \mathrm{cm}^{3}\right)$. The values for laminated board densities 
Physical-Mechanical Properties of Laminated Board Made from Oil Palm Trunk (Elaeis guineensis Jacq.) Waste with Various Lamina Compositions and Densifications

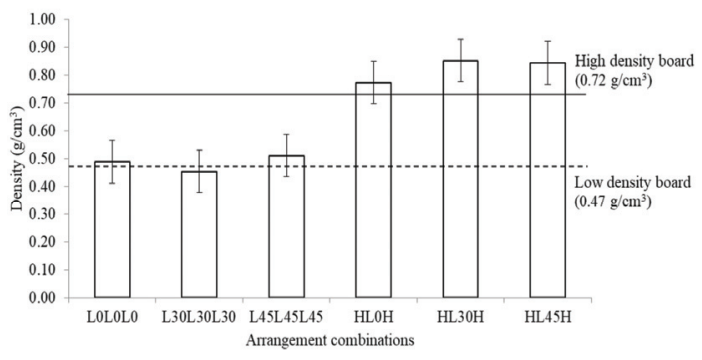

Remarks: solid and dashed line indicated the average values of boards

Fig. 4. Density value of the laminated board; - : the average value high density board; --- : the average low density board.

can be seen in Fig. 4.

The characteristics of the laminated boards produced were influenced by the lamina constituents; the higher the density of the lamina, the better the density of the laminated boards produced (Bodig and Jayne, 1982). Lamina from the outer third of the OPT had a high density because the number of vascular bundles distributed in the trunk tissue is more than in the underlying wood of the OPT. Bakar and H'ng (2008) reported that the vascular bundles are spread unevenly in the OPT, with the amounts being denser in the outside layers and decreasing toward the central part of the trunk.

The results of the analysis of variance in Table 2 show that the arrangement of the laminas influenced the density value of the laminated board, while the densified lamina and the interaction between the lamina arrangement and the densified lamina did not affect the density of the laminated board. Based on the results in Table 2, it can be seen that the density of boards composed of $\mathrm{L}_{0} \mathrm{~L}_{0} \mathrm{~L}_{0}$ laminas was lower than that of $\mathrm{HL}_{0} \mathrm{H}$ boards, which was likely due to the difference in the distribution of the vascular bundles in the OPT. Hartono (2012) indicated that a higher vascular bundle content would increase the content of the fibers that make up the OPT, which would strength the palm oil stem and increase the density value.

\subsection{Modulus of elasticity}

The MOE values ranged from 2.28 GPa to 10.01 $\mathrm{GPa}$, with the highest MOE value being found for the $\mathrm{HL}_{0} \mathrm{H}$ boards (10.01 GPa). The overall MOE values of the laminated boards can be seen in Fig. 5 .

Not all the laminated board MOE values met the JAS 234-2003 standard, which requires a minimum value of $7.3 \mathrm{GPa}$. Combinations that met the standards were $\mathrm{HL}_{0} \mathrm{H}(10.01 \mathrm{GPa}), \mathrm{HL}_{30} \mathrm{H}(9.90 \mathrm{GPa})$, and $\mathrm{HL}_{45} \mathrm{H}$ $(9.13 \mathrm{GPa})$. Laminated boards made with high-density laminas for the outer layers had higher MOE values compared with those with low-density laminas for the outer layers. The average value for the former was 9.87 GPa, which is higher than the MOE of sengon and jabon laminated boards made with phenol-resorcinol formaldehyde and similar to those made with mangium wood (Hendrik et al., 2019).

This is because high-density lamina has thicker cell walls compared with low-density lamina, consequently the high-density lamina potentially has a higher capacity to handle the compression and tension forces.

The MOE values found in this study were higher value than those report by Darwis et al. (2014a), who found that the MOE values of OPT produced from outermost third of the trunk did not met the required standards.

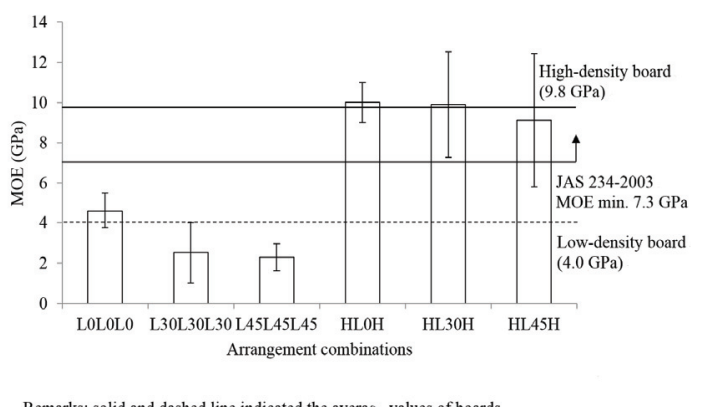

Fig. 5. Modulus of elasticity (MOE) value of the laminated board; - : the average high-density board; --- : the average low-density board. 


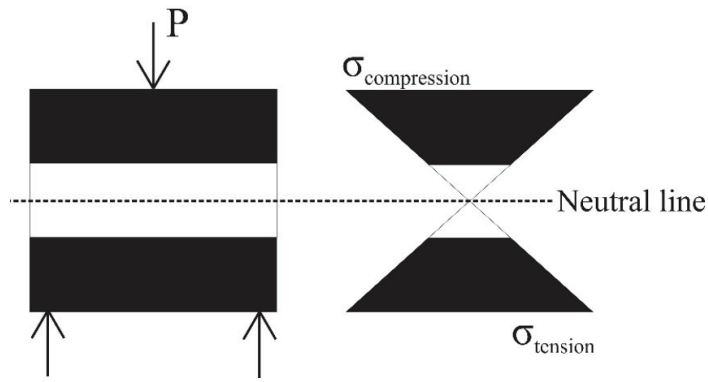

Fig. 6. Beam bending stress diagram.

Based on the analysis of variance (Table 2), only the arrangement of the laminas significantly affected the MOE values of the laminated board. Densification of the core lamina did not significantly affect the MOE value because the compression and tensile forces on the core lamina of laminated board are much smaller than those on the outer laminas. This interpretation is in accordance with the concept of the bending stress diagram shown in Fig. 6. When the load was applied, the top of the laminated board received the maximum compression force, while the bottom part received the maximum tension force. The center layer (i.e., the neutral line) did not experience these compression and tension forces; however, it received maximum shear force. These results indicate that low-quality lamina can be used for the core part of laminated boards.

\subsection{Modulus of rupture}

The MOR value of the laminated board produced ranged from 20.2 $\mathrm{MPa}$ to $56.98 \mathrm{MPa}$, with the highest MOR value being found for $\mathrm{HL}_{30} \mathrm{H}(56.98 \mathrm{MPa})$. The overall MOR of the laminated boards can be seen in Fig. 7.

The MOR values of the laminated boards produced did not all meet the JAS 234-2003 standard, which requires a minimum laminated board MOR value of 29.4 MPa. Combinations that meet the standards were $\mathrm{L}_{0} \mathrm{~L}_{0} \mathrm{~L}_{0}(31.58 \mathrm{MPa}), \mathrm{HL}_{0} \mathrm{H}(53.64 \mathrm{MPa}), \mathrm{HL}_{30} \mathrm{H}$

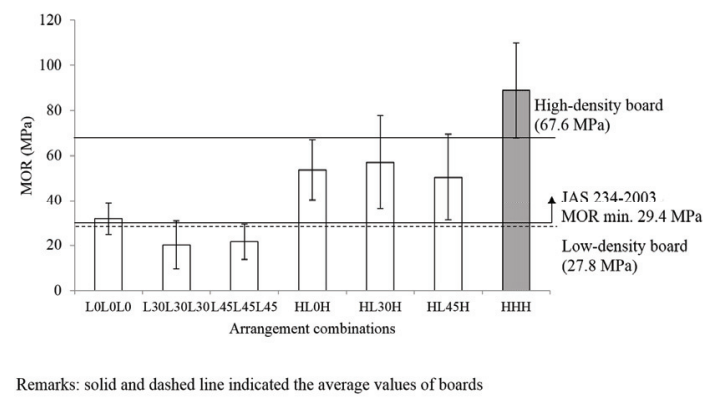

Fig. 7. Modulus of rupture (MOR) value of the laminated board; - : the average all high-density boards; --- : the average low-density board.

(56.98MPa), and $\mathrm{HL}_{45} \mathrm{H}(50.41 \mathrm{MPa})$. Based on the analysis of variance (Table 2), the arrangement of the laminas was the only factor that affected the MOR value. Lestari et al. (2015) and Darwis et al. (2013) stated that the MOR value of laminated board is influenced by the density of the constituent laminas: the higher the density of the constituent laminas, the higher the MOR of the laminated board. The MOR value for the lamina with the highest density in the outer layer was 54.7 MPa. Based on the study by Hendrik et al. (2019), this value is higher than those found for jabon and sengon wood.

The MOR value determines the strength class of the laminated board produced. The results showed that $\mathrm{HL}_{0} \mathrm{H}, \mathrm{HL}_{30} \mathrm{H}$, and $\mathrm{HL}_{45} \mathrm{H}$ laminated boards belonged to strength class III, while $\mathrm{HHH}$ laminated boards belonged to strength class II. According to Martawijaya et al. (2005), the raw materials for structural construction have a minimum requirement of being strength class III.

Thus, even though the laminated board core part received only small tensile or compressive stress, it could reduce the strength class of the laminated board produced; however, the decrease in the strength class was not significant. The combinations $\mathrm{L}_{0} \mathrm{~L}_{0} \mathrm{~L}_{0}$, $\mathrm{L}_{30} \mathrm{~L}_{30} \mathrm{~L}_{30}$, and $\mathrm{L}_{45} \mathrm{~L}_{45} \mathrm{~L}_{45}$ belonged to strength class $\mathrm{V}$, which is not suitable for structural construction (Martawijaya et al., 2005). Strength class values can 
Physical-Mechanical Properties of Laminated Board Made from Oil Palm Trunk

(Elaeis guineensis Jacq.) Waste with Various Lamina Compositions and Densifications

be seen in Table 1 .

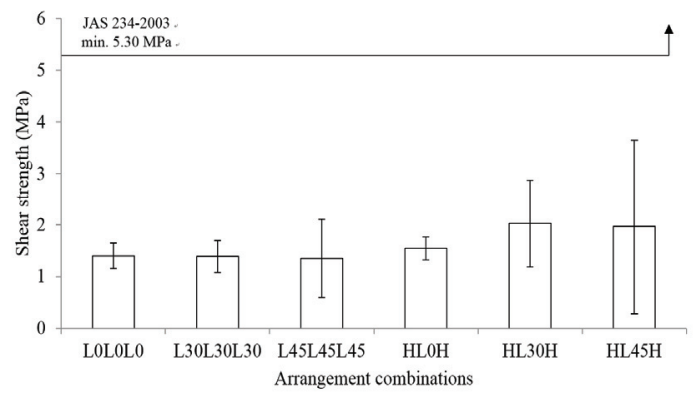

Fig. 8. The value of shear strength the laminated board.

\subsection{Shear strength}

The shear strength values of the laminated boards can be seen in Fig. 8. None of the laminated boards produced met the JAS 234-2003 standard, which requires a minimum laminated board shear strength of 5.3 MPa. The results of the diversity analysis test (Table 2) showed that the arrangement of the lamina, densified lamina in the core layer, and the interaction of these two factors did not significantly affect the shear strength value of the laminated board. However, the laminated board with $\mathrm{HL}_{0} \mathrm{H}$ (1.55 MPa to $2.02 \mathrm{MPa}$ ) had a higher shear strength value than $\mathrm{L}_{0} \mathrm{~L}_{0} \mathrm{~L}_{0}(1.35 \mathrm{MPa}$ to 1.40MPa). The The value of the shear strength of laminated boards with high-density laminas in the outer layers was $1.85 \mathrm{MPa}$. This value was higher than that of jabon wood with phenol-resorcinol formaldehyde adhesive (Hendrik et al., 2019). Santoso et al. (2016) stated that laminated boards composed of high-density wood would have a high shear strength value as well.

\section{CONCLUSION}

Based on the research reported here, it can be concluded that the densification of the core lamina did not significantly affect the physical and mechanical properties of laminated boards. Using high-density laminas for the outer layers of laminated board fulfilled
JAS 234-2003 for MOE and MOR and could be classified as strength class III in Indonesia class strength, which is suitable for structural construction raw materials. However, laminated board made with low-density lamina in the outer layers was classified as strength class $\mathrm{V}$, which is not suitable for raw materials intended for structural construction.

\section{ACKNOWLEDGEMENT}

The research was supported by Ministry of Education and Culture, Republic of Indonesia. The authors also thank to IPB University (Bogor Agricultural University) for supporting research facilities.

\section{REFERENCES}

Amin, Y., Dwianto, W. 2006. Temperature and steam pressure dependency on the fixation of compressed wood by close system compression. Journal of Wood Tropical Science and Technology 4(2): 55-60.

Bakar, E.S., H'ng, P.S. 2008. Anatomical characteristics and utilization of oil palm wood. Sahri M.H., Nobuchi, T. (Editor). The Formation of Wood in Tropical Forest Trees: A Challenge from the Perspective of Functional Wood Anatomy. Universiti Putra Malaysia, Serdang, MY, Malaysia.

Balfas, J. 2006. New approach to oil palm wood utilization for woodworking production, Part 1: Basic properties. Journal of Forestry Research 3(1): 55-66.

Bodig, J., Jayne, B.A. 1982. Mechanics of Wood and Wood Composites. Van Nostrand Reinhold Company, New York, NY, USA.

Byeon, J.W., Kim, T.H., Yang, J.K., Byeon, H.S., Park, H.M. 2017. Bending creep property of crosslaminated woods made with six domestic species. Journal of the Korean Wood Science and Technology 
45(6): 689-702.

Byeon, J.W., Kim, T.H., Yang, J.K., Byeon, H.S., Park, H.M. 2018. Static bending performances of cross-laminated wood panels made with tropical and temperate woods. Journal of the Korean Wood Science and Technology 46(6): 726-734.

Chang, Y.S., Kim, S., Son, W.L., Lee, S.J., Shim, K.B., Yeo, H., Kim, K.W. 2016. Assessment of carbon emission for quantification of environmental load on structural glued laminated timber in Korea. Journal of the Korean Wood Science and Technology 44(3): 449-456.

Darwis, A., Massijaya, M.Y., Nugroho, N., Alamsyah, E.M. 2014a. The characteristics of the laminated board of oil palm trunk. Journal of Wood Tropical Science and Technology 12(2): 157-168.

Darwis, A., Massijaya, M.Y., Nugroho, N., Alamsyah, E.M., Nurrochmat, D.R. 2014b. Bondability of oil palm xylem with isocyanate adhesive. Journal of Wood Tropical Science and Technology 12(1): 39-47.

Darwis, A., Nurrochmat, D.R., Massijaya, M.Y., Nugroho, N., Alamsyah, E.M., Bahtiar, E.T., Safe'I, R. 2013. Vascular bundle distribution effect on density and mechanical properties of oil palm trunk. Asian Journal Plant Science 12(5): 208-213.

Directorate General of Estate Crops. 2018. Tree Crop Estate Statistics of Indonesia Palm Oil 2017-2019. Ministry of Agriculture, Directorate General of Estate Crops, Jakarta, ID, Indonesia.

Febrianto, F., Bakar, E.S. 2004. Kajian Potensi, Sifat-Sifat Dasar dan Kemungkinan Pemanfaatan Kayu Karet dan Biomassa Sawit di Kabupaten Musi Bayuansi (Study of Potential, Basic Characteristics, and Possibility of Utilization of Rubber Wood and Palm Oil Biomass in Musi Bayuansi District). Management Agribusiness and Agroindustry Society Bogor Agricultural University, Bogor, ID, Indonesia.

Hambali, E., Rivai, M. 2017. The Potential of Palm
Oil Waste Biomass in Indonesia in 2020 and 2030. IOP Conf. Series: Earth and Environmental Science 65: 012050. doi:10.1088/1755-1315/65/1/012050

Hartono, R. 2012. Quality enhancement of the inner part of oil palm trunk by close system compression method and by phenol formaldehyde compregnation [dissertation]. Institut Pertanian Bogor, Bogor, ID, Indonesia.

Hartono, R., Wahyudi, I., Febrianto, F., Dwianto, W. 2011. Maximum compression level measurement of oil palm trunk. Journal of Wood Tropical Science and Technology 9(1): 73-83.

Hendrik, J., Hadi, Y.S., Massijaya, M.Y., Santoso, A., Pizzi, A. 2019. Properties of glued laminated timber made from fast-growing species with mangium tannin and phenol resorcinol formaldehyde adhesives. Journal of Korean Wood Science and Technology 47(3): 253-264.

Hong, M.K., Park, B.P., Kim, K.H., Shim, K. 2017. Performance of melamine-urea-formaldehyde resin adhesives at various melamine contents for bonding glued laminated timber under high frequency heating. Journal of the Korean Wood Science and Technology 45(4): 409-418.

Japanese Agricultural Standard. 2003. Glued Laminated Timber. JAS 234. Ministry of Agriculture, Forestry, and Fisheries, Tokyo, JP, Japan.

Jeong, G.Y., Lee, J.J., Yeo, H., Lee, S.S. 2016. Predicting lamina yield from logs of different diameters for cross laminated timber production. Journal of the Korean Wood Science and Technology 44(6): 809-820.

Komariah, R.N., Hadi, Y.S., Massijaya, M.Y., Suryana, J. 2015. Physical-mechanical properties of glued laminated timber made from tropical small-diameter logs grown in Indonesia. Journal of Korean Wood Science and Technology 43(2): 156-167.

Kretschmann, D.E., Green, D.W. 1996. Modelling moisture content-mechanical property relationships 
Physical-Mechanical Properties of Laminated Board Made from Oil Palm Trunk (Elaeis guineensis Jacq.) Waste with Various Lamina Compositions and Densifications

for clear southern pine. Wood and Fiber Science 28(3): 320-337.

Lestari, A.S.R.D., Hadi, Y.S., Hermawan, D., Santoso, A. 2015. Glulam properties of fast-growing species using mahogany tannin adhesive. BioResources 10(4): 7419-7433.

Lestari, A.S.R.D., Hadi, Y.S., Hermawan, D., Santoso, A. 2018. Physical and mechanical properties of glued laminated lumber of pine (Pinus merkusii) and jabon (Anthocephalus cadamba). Journal of Korean Wood Science and Technology 46(2): 143-148.

Martawijaya, A., Kartasujana, I., Kosasi, K., Prawira, S.A. 2005. Atlas Kayu Indonesia Jilid I (Indonesian Wood Atlas Vol I). Forest Products Research and Development Center, Ministry of Forestry, Bogor, ID, Indonesia.

Pramunendar, R.A., Supriyanto, C. 2014. Klasifikasi kualitas kayu kelapa menggunakan gray-level-cooccurrence martix berbasis backpropagation dan algoritma genetika (Quality classification of coconut wood using gray-level co-occurrence martix based on backpropagation and genetic algorithms). National Seminar of Information Technology and Applicable Communication. pp 250-253. ISBN:979-26-0276-3. Santoso, A., Hadi, Y.S., Pizzi, A., Lagel, M.C. 2016. Characterization of merbau wood extract used as an adhesive in glued laminated lumber. Forest Products Journal 66 (5/6): 313-318.

Song, Y.J., Hong, S.I. 2016. Evaluation of bonding strength of larch cross-laminated timber. Journal of the Korean Wood Science and Technology 44(4): 607-615.

Tarigan, R.O., Sucipto, T., Hartono, R. 2015. Variation of outer layer and phenol formaldehyde adhesive glue spread on laminated board quality with core made from oil palm trunk. Peronema Forestry Science Journal (4): 102-110.

Way, C.Y., Bakar, E.S., Ashari, Z., Sahri, M.H. 2010. Treatment of oil palm wood with low-molecularweight phenol-formaldehyde resin and its planing characteristics. Wood Research Journal 1(1): 7-12. 